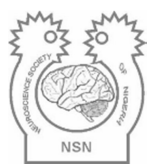

Official Journal of the Neuroscience Society of Nigeria (NSN)
ORIGINAL ARTICLE

http://doi.org/10.47081/njn2021.12.2/003

\title{
Investigating the Effects of Allium sativum on the Prefrontal Cortex in Lithium Chloride Pilocarpine-Induced Epilepsy in Wistar Rat
}

\author{
Sunday Y. Olatunji ${ }^{1}$, Philip O. Ogunnaike ${ }^{1}$, Joshua O. Owolabi ${ }^{1}$, Ayodeji Z. Abijo ${ }^{2}$, \\ Adeshina S. Alabi ${ }^{3}$, Stephen T. Adelodun ${ }^{1}$, John A. Olanrewaju ${ }^{1}$, Adeola S. Adelabi ${ }^{1}$ \\ ${ }^{1}$ Department of Anatomy, Ben Carson School of Medicine, Babcock University, llisan-Remo, Nigeria \\ ${ }^{2}$ Neurobiology Unit, Department of Anatomy, Ladoke Akintola University of Technology Ogbomoso, Nigeria \\ ${ }^{3}$ Neuroregenerative Unit, Department of Anatomy, College of Medicine, University of Ibadan, Ibadan, Nigeria
}

Received:

April 2021

Accepted:

July 2021

\begin{abstract}
The prefrontal cortex (PFC), mediating executive brain functions is impaired in epilepsy. Allium sativum (AS) anti-seizure potential on the PFC of experimentally-induced epilepsy was investigated. Forty-eight male Wistar rats $(200-250 \mathrm{~g})$ were randomized into six groups. Control $(2 \mathrm{~mL} / \mathrm{kg}$ distilled water); AS only (100mg/kg); LiCl+PC (lithium chloride, $127 \mathrm{mg} / \mathrm{kg}$, and pilocarpine, $30 \mathrm{mg} / \mathrm{kg}$ ); LiCl+PC+AS100mg/kg and $\mathrm{LiCl}+\mathrm{PC}+\mathrm{AS} 300 \mathrm{mg} / \mathrm{kg}$ received $\mathrm{LiCl}+\mathrm{PC}$ and $100 \mathrm{mg} / \mathrm{kg} \mathrm{AS}$ and $300 \mathrm{mg} / \mathrm{kg}$ AS respectively; $\mathrm{LiCl}+\mathrm{PC}+\mathrm{SV}$ received $\mathrm{LiCl}+\mathrm{PC}$ and sodium valproate $(10 \mathrm{mg} / \mathrm{kg})$. Treatments lasted for 21 days, behavioural tests then preceded sacrifice. Brain tissues were excised, fixed in $10 \%$ neutral buffered formalin for demonstration of PFC cytoarchitecture and glial fibrillary acidic protein (GFAP) expression. Neurotransmitters were also assayed. Walling and rearing frequencies reduced significantly $(p<0.05)$ in the LiCl+PC group compared to control. Glutamate and acetylcholine levels increased in all groups except AS only, while gamma-aminobutyric acid, dopamine, serotonin and norepinephrine levels increased in the $\mathrm{LiCl}+\mathrm{PC}+\mathrm{AS} 100 \mathrm{mg} / \mathrm{kg}, \mathrm{LiCl}+\mathrm{PC}+\mathrm{AS} 300 \mathrm{mg} / \mathrm{kg}$ and $\mathrm{LiCl}+\mathrm{PC}+\mathrm{SV}$ groups compared to the control. Cytochrome $\mathrm{C}$ oxidase and glucose-6-phosphate dehydrogenase activities significantly increased $(p<0.05)$ in all groups, while nitric oxide levels increased in the $\mathrm{LiCl}+\mathrm{PC}+\mathrm{AS} 300 \mathrm{mg} / \mathrm{kg}$ and $\mathrm{LiCl}+\mathrm{PC}+\mathrm{SV}$ groups compared to the control. Cytoarchitecturally, the LiCl+PC PFC showed neurodegenerative features, increased GFAP expression, while the treated groups showed preserved neurons and mild astrogliosis. Conclusively, AS showed neuroprotective potentials against LiCl+PCinduced neuronal degeneration, mitigated reactive PFC astrogliosis. However, AS did not lower glutamate and other neurotransmitter levels.
\end{abstract}

Key words: Prefrontal cortex; Epilepsy; Pilocarpine; Lithium chloride; Allium sativum; Astrogliosis

\section{INTRODUCTION}

Epilepsy, a neurological disorder characterized by seizures of different forms which could be focal or generalized (Thurman 2007). Millions of people are affected by epilepsy, with most cases being idiopathic. Epilepsy is believed to have strong genetic influence (WHO 2015), while other causes include traumatic brain injury, stroke, brain tumours, infections and birth defects (Goldberg and Coulter 2013). Epileptic seizures are the result of hypersynchronous neuronal discharge (Fisher et al. 2005). People with epilepsy are at increased risks of death and this is often related to the underlying cause of the seizures, status epilepticus, suicide, trauma and sudden unexpected death in epilepsy (Hitiris et al. 2007).

Correspondence: Sunday Y. Olatunji, PhD, Department of Anatomy, Ben Carson School of Medicine, Babcock University, PMB 4005, Ilisan-Remo, Ogun State, Nigeria.. E-mail: olatunjis@babcock.edu.ng; Phone: +2348069019522 
The perception that epilepsy is a brain disorder did not begin until the 18th and 19th century AD, as the initial belief was an affliction by some "gods" (Magiorkinis et al. 2010). The use of anti-epileptic drugs (AED) such as, bromide was introduced in the mid-1800s as the first effective medication (Perucca and Gilliam 2012). The first modern treatment, phenobarbital, was developed in 1912, with phenytoin in use in 1938 (Caravati 2004). Epilepsy caused by unprovoked seizure or interictal spikes can result in cognitive impairment in both humans and rats. Temporal lobe epilepsy which focuses on the hippocampus, the area of the brain responsible for memory consolidation is the most studied form of epilepsy. The prefrontal cortex (PFC), which is associated with frontal lobe epilepsy (FLE) has a crucial role in memory encoding and spatial memory control, and has been reported to be vulnerable in epilepsy (Hernan et al. 2014), although FLE has not been extensively studied. Phylogenetically, the PFC is the last brain area to develop due to its developmental organization. Several experimental rat studies on epilepsy have outlined impairment in reference memory, working memory and long term potentiation (Khan et al. 2010). Presently, there's no cure for epilepsy and the only treatment available is the use of AEDs. Surprisingly, there are intractable and also pharmaco-resistant forms of epilepsy. The surgical method of treatment is also invasive.

Some of these AEDs also present with mild to severe side effects. Research is ongoing as to developing a potential therapeutic drug with no side effects. Researchers from various disciplines are now directing their efforts towards discovering the beneficial effects of Allium sativum on human health. Allium sativum L. (AS) (family Amaryllidaceae), commonly known as garlic, is one of the most widely quoted herbs found in the old medical literatures mainly for its medicinal potentials. Its use as a medicinal herb dates back to about $1550 \mathrm{BC}$, as indicated by its citation in the Ebers Papyrus (Agarwal 1996). In ancient time, AS was used as a preservative for food and as an aid in digestion and respiration to provide energy and elevate depression, and was prescribed for against animal bites, arthritis, and convulsions (Rivlin 2001). The neuroprotective and cognitive improving function of AS has been reported in studies (Ray et al. 2011; Wichai et al. 2019). This study therefore identified a knowledge gap and focuses on exploring the role of AS as a potential anti-convulsant or anti-seizure agent in lithium-pilocarpine model of epilepsy in Wistar rats.

\section{MATERIALS AND METHODS}

\section{Chemicals and Drugs}

Lithium chloride, pilocarpine and sodium valproate were procured from Sigma Aldrich (USA). All other reagents used in this study were of analytical grade and purity

\section{Ethical Approval}

The experimental rats were kept in the experimental animal holding of Babcock University in line with the care and use of animals in research and teaching approved by the Institute of Laboratory Animal Resources, National Research Council, DHHS, pub. no. NIH86-23,1885. Ethical approval for the study was sought and obtained from Babcock University Health Research Ethical Committee (BUHREC) with the BUHREC number: 084/19.

\section{Allium sativum Aqueous Extract Preparation}

Allium sativum aqueous extract preparation was according to the modified method of Belgin et al. (2005). Five hundred grams of AS bulbs obtained from Ilishan Remo Market, Ogun State, were peeled making sure papery skin was completely removed. The cloves were rinsed in clean water, chopped into smaller bits and then air-dried until complete dryness. The peeled garlic cloves was then ground with a warring blender (Waring Commercial, Torrington, CT) with the aid of distilled water. A hundred grams of the ground powder was dissolved in a litre of distilled water $(1: 10 \mathrm{w} / \mathrm{v})$. The extract was filtered through Whatmann number 1 filter paper (Whatman PLC, Middlesex, UK). The filtrate was concentrated under vacuum using a rotary evaporator (HahnShin Scientific, HS-2005-N) and freeze-dried in a lyophilizer (Ilshin Lab. Co. Ltd, Seoul, Republic of Korea) at $-4^{\circ} \mathrm{C}$. The final product (the yield) obtained was stored in a desiccator and refrigerated for use.

\section{Animal Care, Study Design and Procedure}

Male adult Wistar rats (Rattus norvegicus) weighing between 200-250 g were recruited for the study. They were housed in well-ventilated plastic cages within the experimental animal holding of the Babcock University with a $12 \mathrm{~h}$ light and dark succession and allowed adequate access to rat chow and clean water. The forty-eight rats were randomly assigned into six groups $(\mathrm{n}=8)$. Control group received $2 \mathrm{~mL} / \mathrm{kg}$ distilled water; AS only group received $100 \mathrm{mg} / \mathrm{kg}$ AS; LiCl+PC group received 127 mg/kg lithiumchloride ( $\mathrm{LiCl}$ ) and $30 \mathrm{mg} / \mathrm{kg}$ pilocarpine (PC); $\mathrm{LiCl}+\mathrm{PC}+\mathrm{AS} 100 \mathrm{mg} / \mathrm{kg}$ group received $127 \mathrm{mg} / \mathrm{kg}$ $\mathrm{LiCl}, \quad 30 \mathrm{mg} / \mathrm{kg} \mathrm{PC}$ and $100 \mathrm{mg} / \mathrm{kg} \mathrm{AS}$; $\mathrm{LiCl}+\mathrm{PC}+\mathrm{AS} 300 \mathrm{mg} / \mathrm{kg}$ group received $127 \mathrm{mg} / \mathrm{kg}$ $\mathrm{LiCl}, 30 \mathrm{PC}$ and $300 \mathrm{mg} / \mathrm{kg} \mathrm{AS}$; LiCl+PC+SV group received $127 \mathrm{mg} / \mathrm{kg} \mathrm{LiCl,} 30 \mathrm{mg} / \mathrm{kg} \mathrm{PC}$ and $10 \mathrm{mg} / \mathrm{kg}$ sodium valproate (SV).

\section{Seizure Induction}

The method used by Olatunji et al. (2020) was adopted for seizure induction. For seizure induction, the rats were intraperitoneally administered lithium chloride (167 mg/mL) first, followed by pilocarpine (50 $\mathrm{mg} / \mathrm{mL})$. Following administration of Lithium- 
pilocarpine, diazepam (10 $\mathrm{mg} / \mathrm{mL}$ ) was administered intramuscularly and seizure progression was monitored using a webcam. Administration of Allium sativum was done following induction.

\section{Neurobehavioral Assessment}

Behavioural evaluations to observe motor deficits encompassing locomotion, anxiety and memory (working and reference) were carried out on days 14 and 20 preceding sacrifice with the use of the open field box and radial arm maze respectively. For locomotion and anxiety assessment, eight rats from each group were selected and placed in the centre of the apparatus, a white open box $(72 \times 72 \times 36 \mathrm{~cm})$ with black dividing lines. For memory assessment, radial arm maze whose alternate arms were baited was used. Ethanol (70\%) was used to clean both apparatuses in between tests to prevent olfactory cues. The behaviours in the open field box scored included line crossing, and the centre square entries and duration. In the radial arm maze test, the time taken for the rat to identify the baited arm was noted. While exploring, the animals were recorded with a camcorder (DNE webcam, Porto Alegre, Brazil) placed at the top and the video was analysed by independent observers blind to the procedure.

\section{Body and Brain Weights Measurements}

The body weight of each animal was taken prior to sacrifice, while each animal's brain was excised and weighed following sacrifice.

The percentage change in weight was calculated using the formula below:

$\%$ Change in weight $=\frac{\text { Final weight }- \text { Initial weight }}{\text { Initial weight }} \times 100$

\section{Sacrifice and Histological Analysis}

Following cervical dislocation and intracardiac perfusion, the rat brains were carefully excised with bone forceps, blotted dry and weighed with AB204 Mettler Toledo weighing balance. The brains were fixed in $10 \%$ neutral buffered formalin by immersion. One millimetre thick coronal brain slices of the PFC were obtained and processed for routine paraffin embedding. Sections were stained with haematoxylin and eosin for general histoarchitecture demonstration of the PFC, and Bielchowsky stain to demonstrate senile plaques and tangles.

\section{Immunohistochemistry}

The immunohistochemical process was a modified method of Tacos et al. (1982). Prefrontal cortex serial sections $(5 \mu \mathrm{m})$ were taken from paraffin blocks to glass slides and placed on the hot plate at $70^{\circ} \mathrm{C}$ for 1 h. Sections were brought to water and subjected to two changes of xylene, three changes of descending grades of alcohol and to water. Antigen retrieval was performed on the tissue sections by heating on citric acid solution ( $\mathrm{pH}$ 6.0) for 25 min. Tissue sections were equilibrated gradually with cold water to displace the hot citric acid solution for at least $5 \mathrm{~min}$. Peroxidase blocking was done on in $3 \%$ hydrogen peroxide for $15 \mathrm{~min}$. Sections were washed with phosphate buffered saline (PBS) and protein blocking were performed using avidin for $15 \mathrm{~min}$.

Sections were washed with PBS and endogenous biotin in tissues was blocked using biotin for $15 \mathrm{~min}$. After washing with PBS, sections were incubated with the primary antibody (GFAP) at a dilution factor of 1:100. Excess antibody was washed off with PBS and secondary antibody (LINK) was applied for 15 min. Sections were washed and horseradish peroxidase (HRP) was applied for $15 \mathrm{~min}$. 3'3 diaminobenzidine (DAB) solution was applied after washing off the HRP for 5 min. Excess DAB solution and precipitate were washed off. Sections were counterstained with Haematoxylin solution for 2 min, dehydrated in alcohol, cleared in xylene and mounted in distyrene plasticizer xylene (DPX). Immunohistochemical images were captured with a Leica DM750 microscope interfaced with Leica ICC50 camera and digital photomicrographs were archived.

\section{Enzyme Assay}

Cytochrome C oxidase (COX), glucose-6-phosphate dehydrogenase (G6PDH) activities was carried out in PFC tissues of the rats using spectrophotometric technique. Each of the assay kits was procured from Cell Signalling Technologies, Danvers, USA. Dissected brains of rats across groups were weighed and pulverized in $0.25 \mathrm{M}$ sucrose (Sigma) with the aid of an automated homogenizer at $4^{\circ} \mathrm{C}$. Lysates of the PFC were centrifuged for $10 \mathrm{~min}$ in a microfuge at $12,000 \mathrm{rpm}$ to obtain the supernatant containing organelle fragments. The supernatants were aspirated into plain labelled glass cuvette placed in ice. COX and G6PDH activities were assayed according to manufacturer's instructions.

\section{Neurotransmitter Assay}

Prefrontal cortical slices were homogenized. The homogenates were then centrifuged and the supernatant were used to analyse the levels of dopamine, acetylcholine, and serotonin, gamma aminobutyric acid (GABA), glutamate and norepinephrine with standard test kits.

\section{Statistics}

Results obtained were analyzed using GraphPad Prism ${ }^{\circledR}$ software (Version 6.1) and evaluated by analysis of variance (ANOVA). Tukey's post hoc test was used to identify differences between individual means. Significance was set at $p<0.05$. Bar charts were used to represent outcomes with error bars showing the mean \pm SEM respectively. 


\section{RESULTS}

\section{Body Weight and Relative Brain Weight}

There was no significant difference in the percentage body weight change and also in the relative brain weight of the rats when the experimental groups were compared to the control group ( $p=0.270$ and 0.906 , respectively).
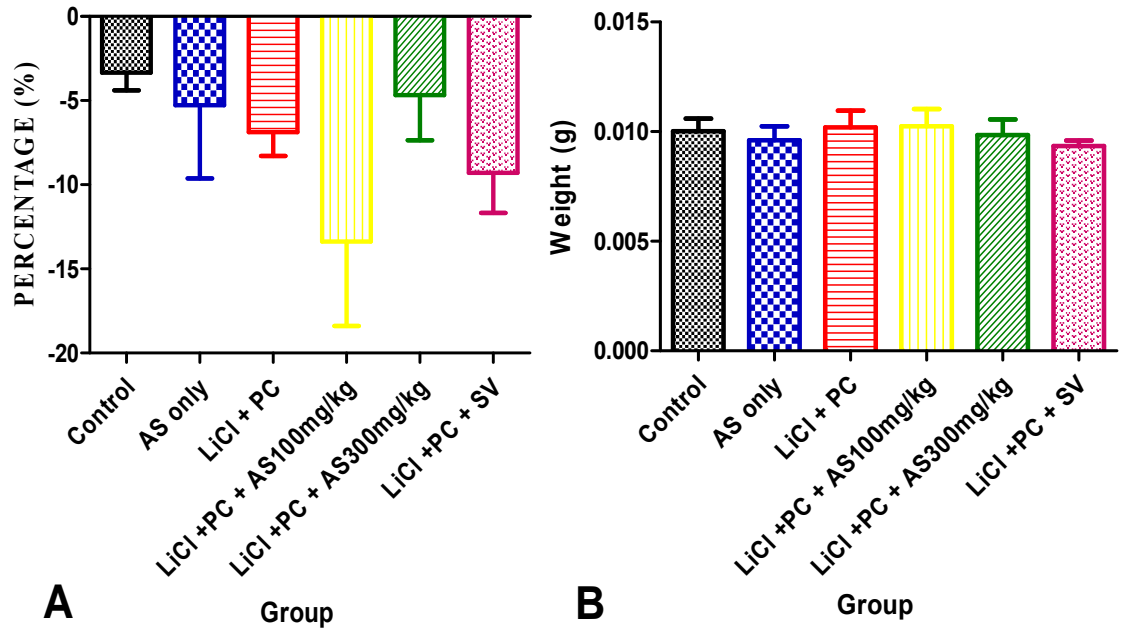

Fig. 1: Percentage body weight change and relative brain weight of rats across groups. A: Percentage weight change; B: Relative brain weight; There was no significant difference in percentage body weight and relative brain weight of animals in all groups at $p<0.05$ compared to the control. Values are expressed as mean \pm SEM. AS - Allium sativum; $\mathrm{LiCl}$ - lithium chloride; PC - pilocarpine; SV sodium valproate

Histological and
Immunohistochemical
Assessments
Histological evaluation
of the PFC in the H and
E stained photomicro-
graphs (Fig. 2) showed
that the control and AS
only groups revealed
normal appearing cellu-
lar architecture. Neuro-
nal degeneration was
evident in the LiCl+PC
group, with neurons
exhibiting degenerative
features and scattered
within neuropils. The
AS and SV treated
groups, LiCl+PC+AS
$100 m g / k g, ~ L i C l+P C+A S$
$300 m g / k g$ and LiCl+PC
$+S V$ showed mild
neurodegenerative fea-
tures, with degenerate-
ng neurons having ng neurons having
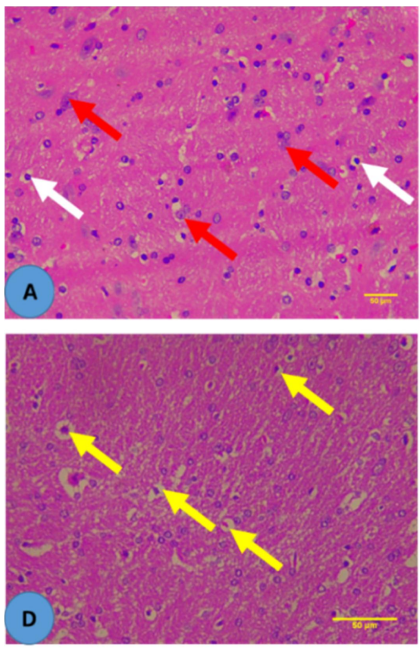

karyorrhectic appearance.

Immunohistochemically, the PFC showed increased immunoreactivity to GFAP in the $\mathrm{LiCl}+\mathrm{PC}$ only group, which was characterized by hypertrophied astrocytes with altered morphologies, while the control and AS only groups showed normal morphology of astrocytes. The $\mathrm{LiCl}+\mathrm{PC}+\mathrm{AS} 100 \mathrm{mg} / \mathrm{kg}$, $\mathrm{LiCl}+\mathrm{PC}+\mathrm{AS}$ $300 \mathrm{mg} / \mathrm{kg}$ and $\mathrm{LiCl}+\mathrm{PC}+\mathrm{SV}$ groups showed mild to moderate astrogliosis (Fig. 3).

\section{Neurobehavioral Assessment}

Behavioural tests results are presented in Fig. 4. Fig. 4A-G shows graph of behavioural tests of the open field test while Fig. $4 \mathrm{H}-\mathrm{K}$ represents behavioural analysis of the radial arm maze test in all groups. There was no significant difference in line crossing in all experimental groups relative to the control group ( $p=0.273)$ (Fig. 4A). In Fig. $4 \mathrm{~B}$, there was increased rearing frequency in AS only, however this was not statistically significant when compared to the control $(p=0.117)$. There was significant reduction in the frequency of walling (Fig. 4C) in $\mathrm{LiCl}+\mathrm{PC}+\mathrm{AS}$ $100 \mathrm{mg} / \mathrm{kg}$ group compared to the control $(p=0.013)$. Fig. 4D shows that there was no significant difference in grooming behaviour across the groups $(p=0.645)$. In

Fig. 4E there was significant reduction in rearing
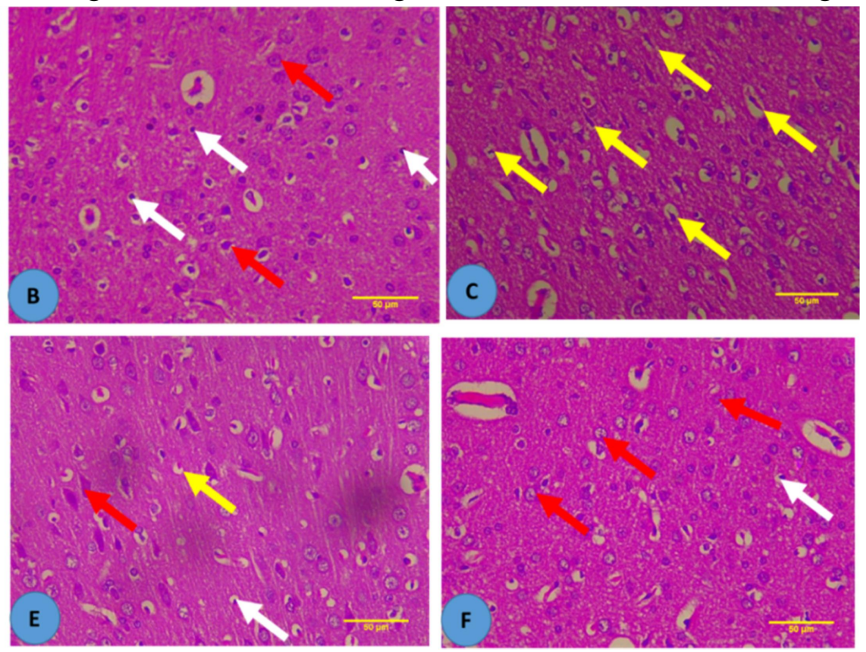

Fig. 2: Representative photomicrographs of the prefrontal cortex of rats in the $\mathrm{LiCl}+\mathrm{PC}$ model of epilepsy. A (Control) and B (AS only), shows a normal morphology. Neurons exhibiting degenerative features are scattered within neuropils in C ( $\mathrm{LiCl}+\mathrm{PC}$ group) treated with lithium-pilocarpine only, while $D$ and $E$, AS treated groups ( $\mathrm{LiCl}+\mathrm{PC}+\mathrm{AS} 100 \mathrm{mg} / \mathrm{kg}$ and $\mathrm{LiCl}+\mathrm{PC}+\mathrm{AS} 300 \mathrm{mg} / \mathrm{kg}$, respectively) and SV treated group (LiCl+PC+SV) show mild neurodegenerative features. H\&E, $\times 400$. Red arrow: normal neurons; yellow arrow: degenerating neurons; white arrows: oligodendrocytes. AS - Allium sativum; $\mathrm{LiCl}$ - lithium chloride; PC - pilocarpine; SV - sodium valproate. Scale bars - $50 \mu \mathrm{m}$ 

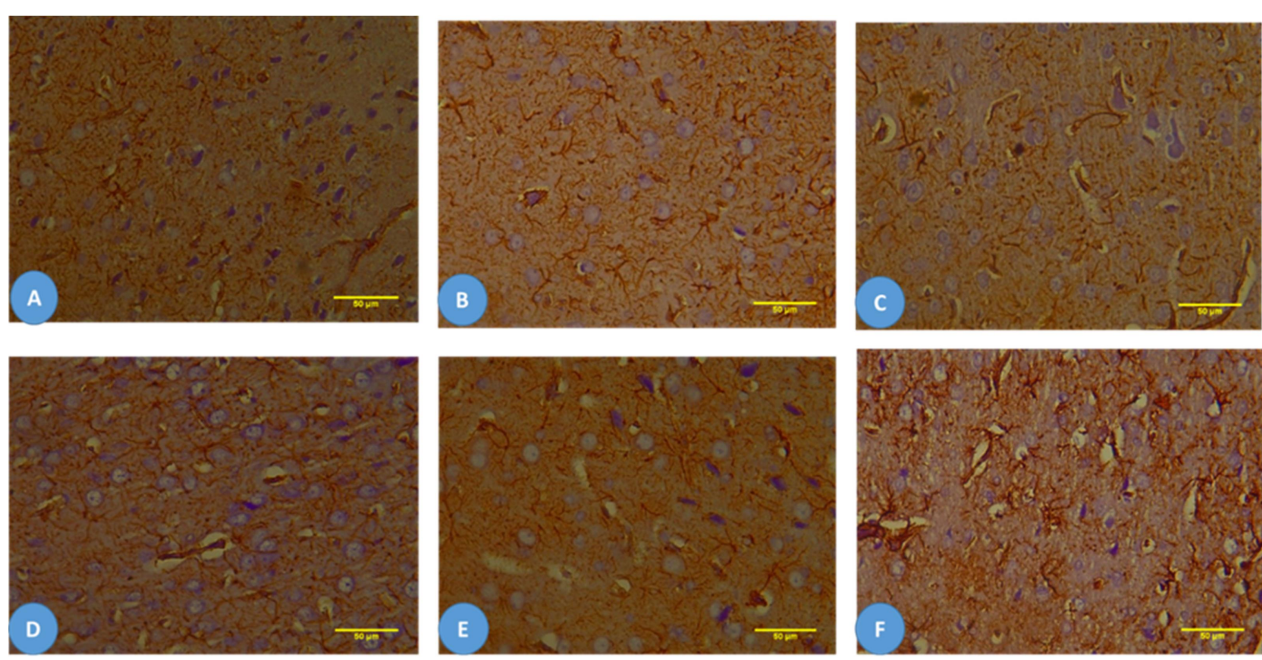

Fig. 3: Immunohistochemical labelling of astrocytes in the prefrontal cortex of rats with GFAP. In LiCl+PC only group (C) is increased immunoreactivity to GFAP marked by the presence of hypertrophied astrocytes with altered morphologies, while control (A) and AS only (B) groups show normal morphology of astrocytes. $\mathrm{LiCl}+\mathrm{PC}+\mathrm{AS} 100 \mathrm{mg} / \mathrm{kg}$ (D), $\mathrm{LiCl}+\mathrm{PC}+\mathrm{AS} 300 \mathrm{mg} / \mathrm{kg} \mathrm{(E)}$ and $\mathrm{LiCl}+\mathrm{PC}+\mathrm{SV}(\mathrm{F})$ show mild to moderate astrogliosis. White arrow: astrocytes with normal morphology; red arrow: hypertrophied astrocytes. Scale bars - 50 $\mu \mathrm{m}$

frequency in $\mathrm{LiCl}+\mathrm{PC}+\mathrm{AS} 300 \mathrm{mg} / \mathrm{kg}$ group compared to the control $(p=0.038)$. There was also a significant reduction in rearing frequency in $\mathrm{LiCl}+\mathrm{PC}+\mathrm{AS} 100$ $\mathrm{mg} / \mathrm{kg}, \quad \mathrm{LiCl}+\mathrm{PC}+\mathrm{AS} 300 \mathrm{mg} / \mathrm{kg}$ and $\mathrm{LiCl}+\mathrm{PC}+\mathrm{SV}$ groups relative to AS only group. In Fig. 4F and 4G, there was no significant difference in centre square entry and centre square duration across groups. Fig. 4F-4K, showed no significant difference when comparing the experimental groups to the control and between groups at $p<0.05$.

\section{Neurotransmitter Assessment}

The levels of neurotransmitters, dopamine, glutamate, acetylcholine, GABA, serotonin, and norepinephrine are as shown in Fig. 5.

Dopamine levels in the $\mathrm{LiCl}+\mathrm{PC}+\mathrm{AS} 100 \mathrm{mg} / \mathrm{kg}$, $\mathrm{LiCl}+\mathrm{PC}+\mathrm{AS} 300 \mathrm{mg} / \mathrm{kg}$ and $\mathrm{LiCl}+\mathrm{PC}+\mathrm{SV}$ groups were significantly higher compared to the control $(p=0.0006)$. There were also significant higher dopamine levels in the $\mathrm{LiCl}+\mathrm{PC}+\mathrm{AS} 300 \mathrm{mg} / \mathrm{kg}$ and $\mathrm{LiCl}+\mathrm{PC}+\mathrm{SV}$ groups relative to $\mathrm{AS}$ only group $(p=0.0006)$ and in $\mathrm{LiCl}+\mathrm{PC}+\mathrm{SV}$ group relative to $\mathrm{LiCl}+\mathrm{PC}$ group $(p=0.0006)$.

Glutamate level was significantly higher $(p=0.0006)$ in the $\mathrm{LiCl}+\mathrm{PC}, \quad \mathrm{LiCl}+\mathrm{PC}+\mathrm{AS} 100 \mathrm{mg} / \mathrm{kg}, \quad \mathrm{LiCl}+\mathrm{PC}+\mathrm{AS}$ $300 \mathrm{mg} / \mathrm{kg}$ and $\mathrm{LiCl}+\mathrm{PC}+\mathrm{SV}$ groups relative to the control and AS only groups. However, there was significant decreased glutamate levels in the $\mathrm{LiCl}+\mathrm{PC}+\mathrm{AS} 300 \mathrm{mg} / \mathrm{kg}$ group $(p=0.0006)$ when compared to $\mathrm{LiCl}+\mathrm{PC}+\mathrm{AS} 100 \mathrm{mg} / \mathrm{kg}$ group. Acetylcholine was significantly higher $(p=0.0006)$ in the $\mathrm{LiCl}+\mathrm{PC}, \mathrm{LiCl}+\mathrm{PC}+\mathrm{AS} 100 \mathrm{mg} / \mathrm{kg}, \mathrm{LiCl}+\mathrm{PC}+\mathrm{AS}$ $300 \mathrm{mg} / \mathrm{kg}$ and $\mathrm{LiCl}+\mathrm{PC}+\mathrm{SV}$ groups relative to the control and the AS only group. $\mathrm{LiCl}+\mathrm{PC}+\mathrm{SV}$ group showed significant higher $(p=0.0006)$ in acetylcholine levels when compared to $\mathrm{LiCl}+\mathrm{PC}$ group.

The $\mathrm{LiCl}+\mathrm{PC}+\mathrm{AS} 100 \mathrm{~m}$ $\mathrm{g} / \mathrm{kg}, \quad \mathrm{LiCl}+\mathrm{PC}+\mathrm{AS} 300$ $\mathrm{mg} / \mathrm{kg}$ and $\mathrm{LiCl}+\mathrm{PC}$ $+S V$ groups showed significant higher $(p=$ 0.0006) GABA levels relative to the control. GABA levels was also significant higher $(p=$ 0.0006) in $\mathrm{LiCl}+\mathrm{PC}+\mathrm{AS}$ $300 \mathrm{mg} / \mathrm{kg}$ and $\mathrm{LiCl}+\mathrm{PC}$ $+S V$ groups when compared to the AS only group. $\mathrm{LiCl}+\mathrm{PC}+$ SV group also showed significant higher $(p=$ 0.0006 ) when compared to the $\mathrm{LiCl}+\mathrm{PC}$ group.

Levels of serotonin was significantly higher $(p=0.0006)$ in the $\mathrm{LiCl}+\mathrm{PC}+\mathrm{AS}$ $100 \mathrm{mg} / \mathrm{kg}, \mathrm{LiCl}+\mathrm{PC}+\mathrm{AS} 300 \mathrm{mg} / \mathrm{kg}$ and $\mathrm{LiCl}+\mathrm{PC}+\mathrm{SV}$ groups relative to the control. There was also a significant higher $(p=0.0006)$ serotonin level in the $\mathrm{LiCl}+\mathrm{PC}+\mathrm{SV}$ group when compared to the AS only group.

Norepinephrine levels was significantly higher $(p=0.0006)$ in the $\mathrm{LiCl}+\mathrm{PC}+\mathrm{AS} 100 \mathrm{mg} / \mathrm{kg}, \mathrm{LiCl}+\mathrm{PC}+$ $\mathrm{AS} 300 \mathrm{mg} / \mathrm{kg}$ and $\mathrm{LiCl}+\mathrm{PC}+\mathrm{SV}$ groups relative to the control. There was also a significant higher norepinephrine level $(p=0.0006)$ in the $\mathrm{LiCl}+\mathrm{PC}+\mathrm{AS}$ $300 \mathrm{mg} / \mathrm{kg}$ and $\mathrm{LiCl}+\mathrm{PC}+\mathrm{SV}$ groups when compared to the AS only and $\mathrm{LiCl}+\mathrm{PC}$ groups. Only $\mathrm{LiCl}+\mathrm{PC}+\mathrm{SV}$ group showed significant higher norepinephrine level $(p=0.0006)$ when compared to the $\mathrm{LiCl}+\mathrm{PC}+\mathrm{AS} 100 \mathrm{mg} / \mathrm{kg}$ group.

\section{Enzyme Assessment}

The results of enzyme assay are as shown in Fig. 6. Activities of COX, G6PDH and nitric oxide in the prefrontal cortices showed significant differences when compared to the control and also between the experimental groups.

Figure 6A represents COX activity in the PFC, and was significantly higher $(p<0.0001)$ in all experimental groups relative to control. There was also significant higher levels of $\operatorname{COX}(p<0.0001)$ in the $\mathrm{LiCl}+\mathrm{PC}+\mathrm{AS} 100 \mathrm{mg} / \mathrm{kg}, \quad \mathrm{LiCl}+\mathrm{PC}+\mathrm{AS} 300 \mathrm{mg} / \mathrm{kg}$ and $\mathrm{LiCl}+\mathrm{PC}+\mathrm{SV}$ groups when compared to the AS only and $\mathrm{LiCl}+\mathrm{PC}$ groups. $\mathrm{LiCl}+\mathrm{PC}+\mathrm{AS} 300 \mathrm{mg} / \mathrm{kg}$ and $\mathrm{LiCl}+\mathrm{PC}+\mathrm{SV}$ groups showed significant $(\mathrm{p}<0.0001)$ higher $\mathrm{COX}$ level when compared to the $\mathrm{LiCl}+\mathrm{PC}+\mathrm{AS} 100 \mathrm{mg} / \mathrm{kg}$ group. $\mathrm{LiCl}+\mathrm{PC}+\mathrm{SV}$ group showed significant higher $(p<0.0001)$ COX level when compared to the $\mathrm{LiCl}+\mathrm{PC}+\mathrm{AS} 300 \mathrm{mg} / \mathrm{kg}$ group. 
In Fig. 6B, all experimental groups showed a significantly higher $(p<0.0001)$ G6PDH activity relative to the control. There was also a significant higher $(p<0.0001)$ G6PDH activity in the $\mathrm{LiCl}+\mathrm{PC}$ $+\mathrm{AS} 100 \mathrm{mg} / \mathrm{kg}, \mathrm{LiCl}+\mathrm{PC}+\mathrm{AS} 300 \mathrm{mg} / \mathrm{kg}$ and $\mathrm{LiCl}+\mathrm{PC}$ $+S V$ groups when compared to the AS only and $\mathrm{LiCl}+\mathrm{PC}$ groups. Only in the $\mathrm{LiCl}+\mathrm{PC}+\mathrm{SV}$ group that G6PDH activity was significant higher $(p<0.0001)$ when compared to groups $\mathrm{LiCl}+\mathrm{PC}+\mathrm{AS} 300 \mathrm{mg} / \mathrm{kg}$ and $\mathrm{LiCl}+\mathrm{PC}+\mathrm{SV}$.

In Fig. 6C, there was higher nitric oxide (NO) in the $\mathrm{LiCl}+\mathrm{PC}+\mathrm{AS} 300 \mathrm{mg} / \mathrm{kg}$ and $\mathrm{LiCl}+\mathrm{PC}+\mathrm{SV}$ groups $(p<0.0001)$ when compared to the control, AS only and $\mathrm{LiCl}+\mathrm{PC}+\mathrm{AS} 100 \mathrm{mg} / \mathrm{kg}$ groups. Although $\mathrm{NO}$ activity decreased in the $\mathrm{AS}$ only, $\mathrm{LiCl}+\mathrm{PC}$ and $\mathrm{LiCl}+\mathrm{PC}+\mathrm{AS} 100 \mathrm{mg} / \mathrm{kg}$ groups, this was not significant $(p<0.05)$ when compared to the control. Only in the $\mathrm{LiCl}+\mathrm{PC}+\mathrm{SV}$ group was $\mathrm{NO}$ activity significantly $(p<0.0001)$ higher when compared to $\mathrm{LiCl}+\mathrm{PC}$ group.

\section{DISCUSSION}

The study investigated the state of the PFC in lithium chloride-pilocarpine model of epilepsy and the role of
AS on PFC histomorphology, astrocyte morphology, neurotransmitters, enzymes and behavioural changes. AS has many health benefits and has been traditionally used worldwide over the centuries. The anti-oxidant and anti-inflammatory potentials of AS has been documented extensively with its beneficial effects on neuronal physiology and brain function (Carmia 2006). Free radicals generation remains one of the known causes of epileptic seizures (Ashrafi et al. 2007). Free radicals are molecular fragments containing one or more unpaired electrons causing oxidative stress due to excessive production of reactive oxygen (ROS) species. The brain is prone to the damaging effect of reactive oxidative stress due to its high oxygen requirement, abundant mitochondria and high metabolic rate. Persistent seizures promote the increase of ROS production which results in oxidative damage of the biomolecules (Diniz et al. 2015). Oxidative stress has been implicated as one of the possible mechanism involved in the initiation and progression of epileptogenesis (Diniz et al. 2015). The findings from this study shows no significant effect on the body weight changes and brain weights following induction with $\mathrm{LiCl}+\mathrm{PC}$ and treatment with $\mathrm{AS}$ across groups relative to the control.
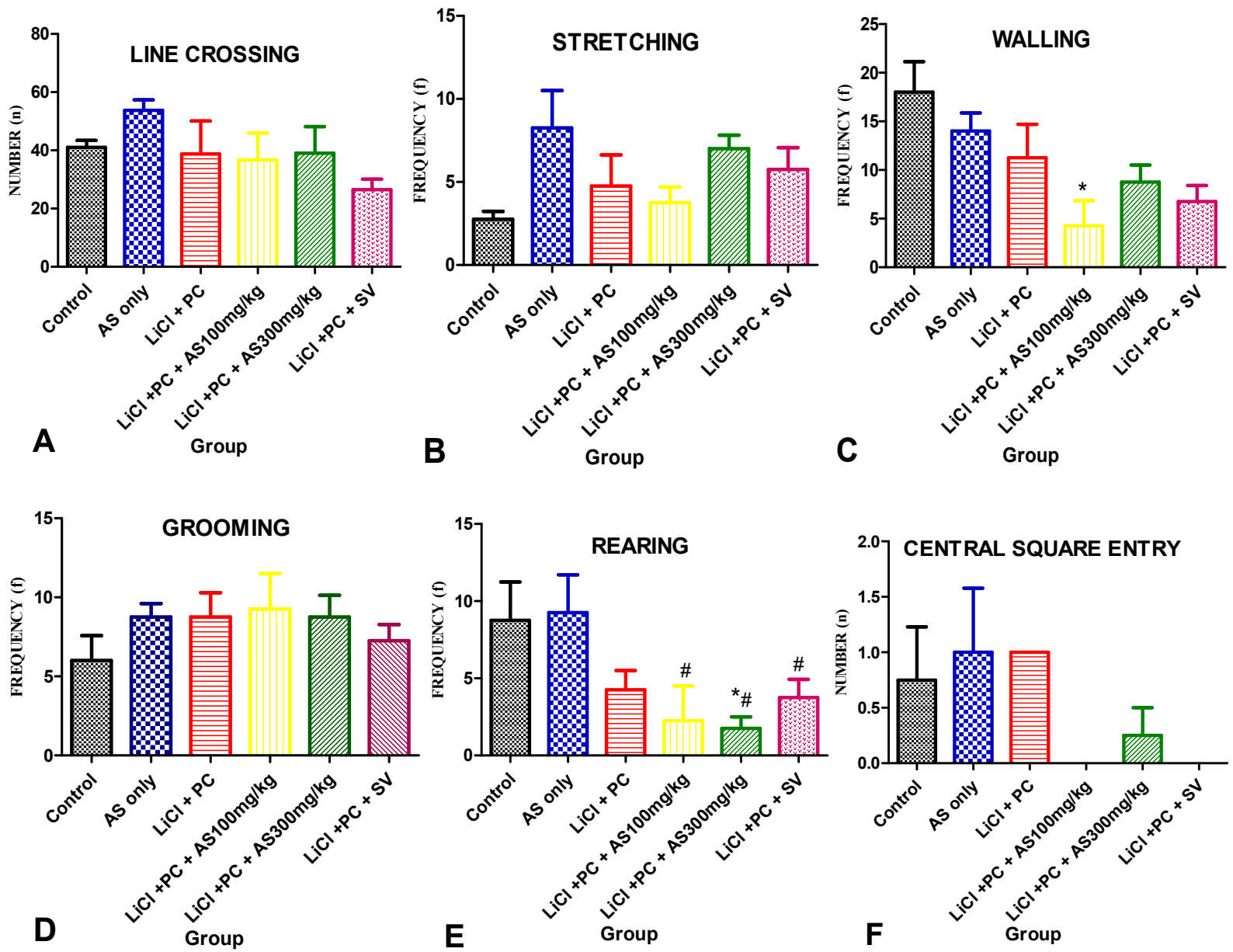


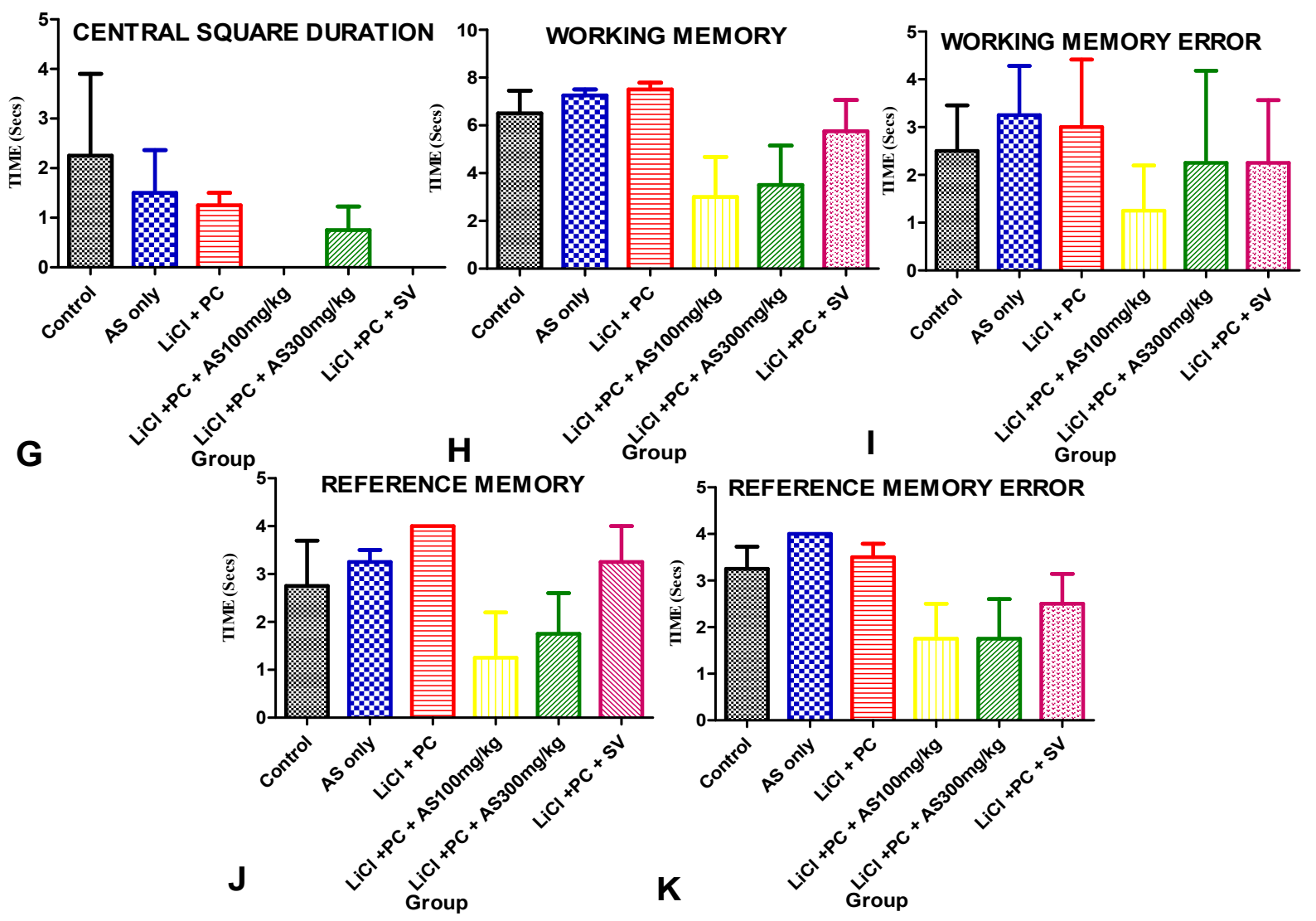

Fig. 4: Neurobehavioural parameters of the rats. A-G: Open field test; H-K: Radial arm-maze test. A: Line crossing; B: Stretching; C: Walling; D: Grooming; E: Rearing; F: Central square entry; G: Central square duration; H: Working Memory; I: Working memory error; J: Reference memory; K: Reference memory error. Values are expressed as mean \pm SEM in all groups. AS - Allium sativum; $\mathrm{LiCl}$ - lithium chloride; PC - pilocarpine; SV - sodium valproate. * Significance relative to control; \# Significant difference relative to AS only group $(p<0.05)$.

Assessment of neuronal morphology in the prefrontal cortices of rats induced with $\mathrm{LiCl}+\mathrm{PC}$ showed neurons exhibiting degenerative features scattered within neuropils, while the groups that received the AS extract only and treated with the extract or the standard drug showed improvement in neuronal morphology. Oxidative stress and mitochondrial dysfunction have been implicated as some of the various mechanisms involved in neurodegeneration in kainic acid and $\mathrm{LiCl}+\mathrm{PC}$ Wistar rat models of epilepsy (Waldbaum and Patel 2010; Sharma et al. 2018). The main events occurring in epileptogenesis involves ROS/reactive nitrogen species production, excessive production of pro-inflammatory mediators, neurodegeneration, excessive anomalous neurogenesis, reorganization of survived neuronal circuits, maladaptive dendritic plasticity, axonal sprouting within excitatory pathways accompanied by loss of inhibitory interneurons, reactive gliosis, damage to the blood-brain barrier, re-arrangement of the extracellular matrix and neuronal cytoarchitecture (Amini et al. 2015; Kalozoumi et al. 2018).

The neuroprotective ability following treatment with AS extract in groups with prior administration of
$\mathrm{LiCl}+\mathrm{PC}$ could be attributed to the anti-oxidant properties of the plant. The phytochemical screening of aqueous, ethyl acetate, methanol and hexane extracts of AS revealed the presence of flavonoids, steroids, saponin, glycosides, phenolic compounds, terpenoids, carbohydrate and alkaloids (Divya et al. 2017). Since flavonoid is one of the phytochemical constituents of AS, experimental studies have demonstrated the anti-epileptic activity flavonoids possess by modulating the $\mathrm{GABA}_{A}-\mathrm{Cl}$ channel complex with their structural similarities to benzodiazepines (Choudhary et al. 2011).

Glial fibrillary acidic protein (GFAP) is a major intermediate filament protein in astrocytes. Increased GFAP expression is indicative of reactive gliosis, and reactive gliosis is one of the features of epileptogenesis. In this study, there were expressions of GFAP immunoreactivity in all the groups. However, in $\mathrm{LiCl}+\mathrm{PC}$ only group, there was increased GFAP immunoreactivity, while other groups showed mild to moderate astrogliosis. This finding is in tandem with Brigo et al. (2012), who observed astrogliosis in mouse hippocampal formation following $\mathrm{LiCl}+\mathrm{PC}$ induced status epilepticus. Reduction in the 
expression of an astrocyte-specific enzyme, glutamine synthetase that converts synaptically released glutamate into glutamine, a precursor for glutamate and GABA synthesis has been reported by Clasadonte and Haydon 2012. It has been proven that selective reactive astrocytosis, and the accompanying loss of glutamine synthetase, leads to reduced synaptic inhibition and increased spread of excitation. In addition, reactive astrocytes exhibit increased expression of adenosine kinase, the enzyme responsible for converting adenosine, an endogenous anticonvulsant (Clasadonte and Haydon 2012). The mild astrogliosis observed in the treated groups could be attributed to the ability of AS to attenuate reactive astrogliosis.

An alteration in the neurotransmitter system is a major mechanism of epileptogenesis. In this study, glutamate level in the prefrontal cortices was significantly elevated in the $\mathrm{LiCl}+\mathrm{PC}, \mathrm{LiCl}+\mathrm{PC}+\mathrm{AS}$ $100 \mathrm{mg} / \mathrm{kg}, \mathrm{LiCl}+\mathrm{PC}+\mathrm{AS} 300 \mathrm{mg} / \mathrm{kg}$ and $\mathrm{LiCl}+\mathrm{PC}+\mathrm{SV}$ groups when compared to the control and the AS only groups. This is suggestive of increased or

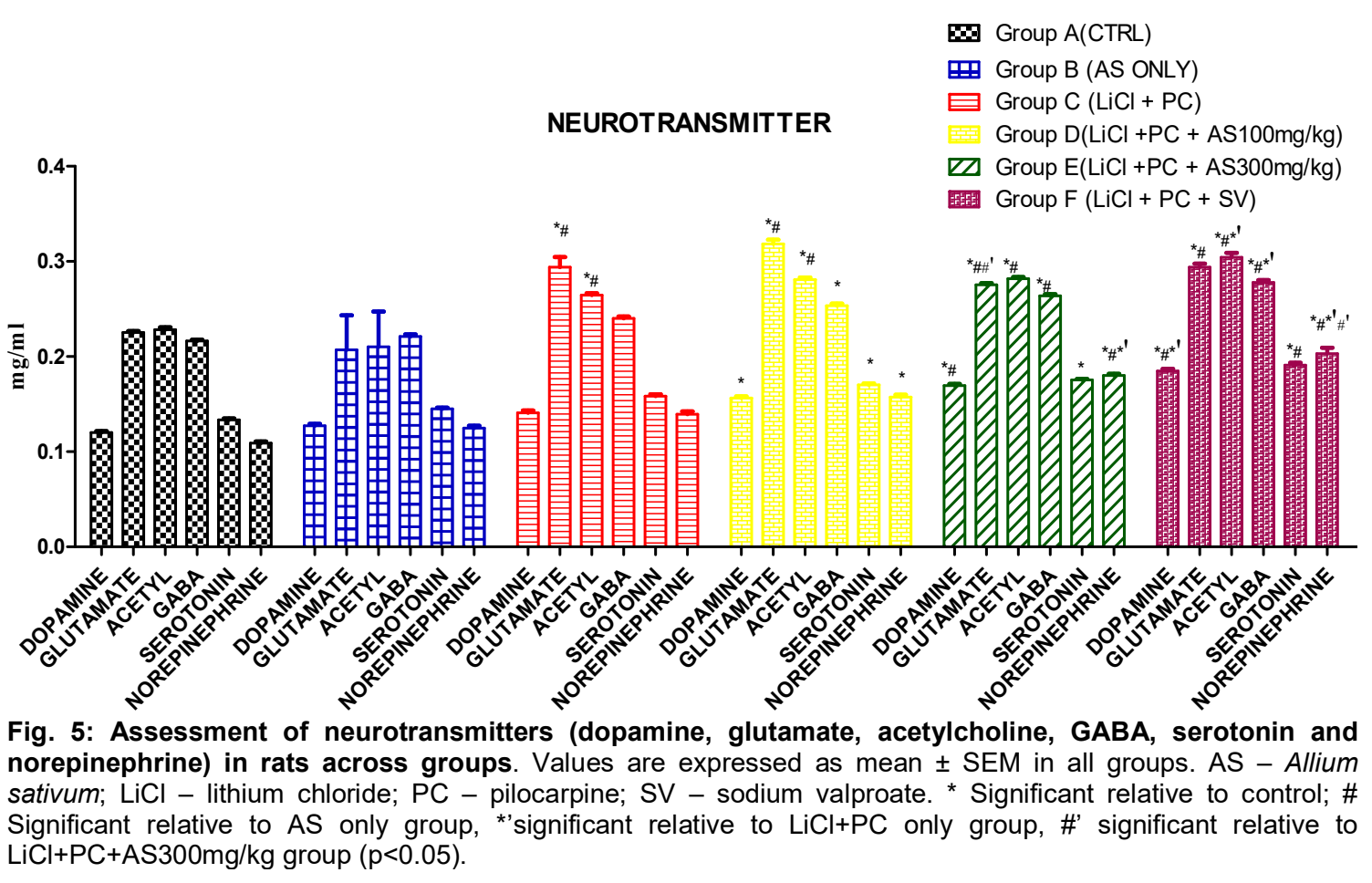

Fig. 5: Assessment of neurotransmitters (dopamine, glutamate, acetylcholine, GABA, serotonin and norepinephrine) in rats across groups. Values are expressed as mean \pm SEM in all groups. AS - Allium sativum; $\mathrm{LiCl}$ - lithium chloride; PC - pilocarpine; SV - sodium valproate. * Significant relative to control; \# Significant relative to AS only group, *'significant relative to $\mathrm{LiCl}+\mathrm{PC}$ only group, \#' significant relative to $\mathrm{LiCl}+\mathrm{PC}+\mathrm{AS} 300 \mathrm{mg} / \mathrm{kg}$ group $(\mathrm{p}<0.05)$.

\section{CYTOCHROME-C-OXIDASE GLUCOSE-6-PHOSPHATE DEHYDROGENASE NITRIC OXIDE}

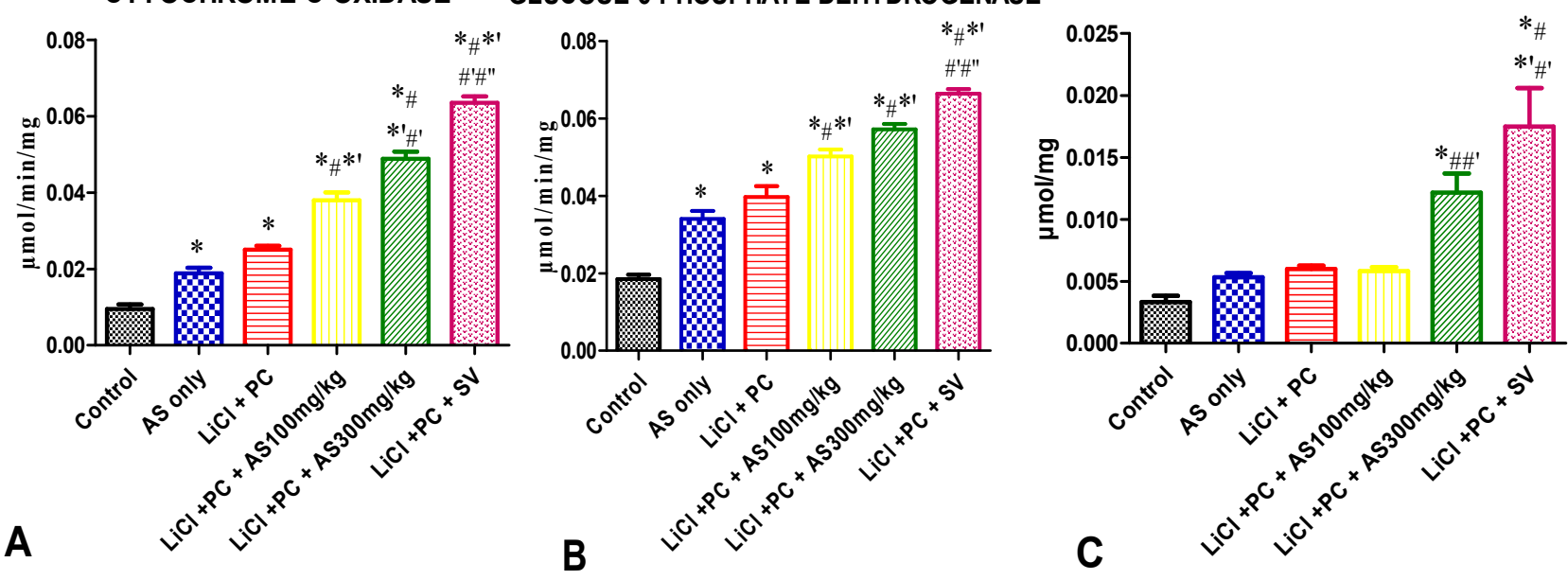

Fig. 6: Cytochrome $C$ oxidase, glucose 6 phosphate dehydrogenase activities and nitric oxide level in rats across groups. Values are expressed as mean \pm SEM in all groups. AS - Allium sativum; LiCI - lithium chloride; PC pilocarpine; SV - sodium valproate. *Significant relative to control; \# Significant relative to AS only group; *'significant relative to $\mathrm{LiCl}+\mathrm{PC}$ only group; \#' significant relative to $\mathrm{LiCl}+\mathrm{PC}+\mathrm{AS} 100 \mathrm{mg} / \mathrm{kg}$; \#" significant relative to $\mathrm{LiCl}+\mathrm{PC}+\mathrm{AS} 300 \mathrm{mg} / \mathrm{kg}(\mathrm{P}<0.05)$. 
enhanced glutamatergic transmission following $\mathrm{LiCl}+\mathrm{PC}$ induction (Werner and Covenas 2011). Hyperexcitation without subsequent inhibition caused by the excitatory neurotransmitter glutamate is one of the major causes of epileptic seizures. Excess glutamate overstimulates $\mathrm{N}$-methyl-D-aspartate (NMDA) receptors leading to increased intracellular $\mathrm{Ca}^{2+}$ and excitotoxicity. Currently available AEDs target $\mathrm{Na}^{+}$and $\mathrm{Ca}^{2+}$ channels thereby facilitating GABAergic inhibition or reducing glutamatergic neurotransmission (Lin et al. 2012).

In this study, the GABA level was significantly increased in the $\mathrm{LiCl}+\mathrm{PC}+\mathrm{AS} 100 \mathrm{mg} / \mathrm{kg}, \mathrm{LiCl}+\mathrm{PC}+\mathrm{AS}$ $300 \mathrm{mg} / \mathrm{kg}$ and $\mathrm{LiCl}+\mathrm{PC}+\mathrm{SV}$ groups. GABA, an inhibitory neurotransmitter also plays a role in epileptogenesis and other neurological disorders. It is widely distributed in the central nervous system and exerts a presynaptic inhibitory action by acting via $\mathrm{GABA}_{A}$ and $G_{A B A_{B}}$ receptors. These receptors have the inherent ability to move from synaptic to extrasynaptic localizations (Jacob et al. 2008). GABA agonist suppresses epileptic seizures, while drugs that antagonize GABA release induces epileptic seizures. There was consistency in the levels of dopamine, serotonin and norepinephrine in the $\mathrm{LiCl}+\mathrm{PC}+\mathrm{AS}$ $100 \mathrm{mg} / \mathrm{kg}, \mathrm{LiCl}+\mathrm{PC}+\mathrm{AS} 300 \mathrm{mg} / \mathrm{kg}$ and $\mathrm{LiCl}+\mathrm{PC}+\mathrm{SV}$ groups when compared with the control. The levels of acetylcholine increased in the $\mathrm{LiCl}+\mathrm{PC}, \mathrm{LiCl}+\mathrm{PC}+\mathrm{AS}$ $100 \mathrm{mg} / \mathrm{kg}, \mathrm{LiCl}+\mathrm{PC}+\mathrm{AS} 300 \mathrm{mg} / \mathrm{kg}$ and $\mathrm{LiCl}+\mathrm{PC}+\mathrm{SV}$ groups when compared to the control. Serotonin, mainly a postsynaptic excitatory neurotransmitter, has a modulating effect on epileptogenesis (Meurs et al. 2008). The levels of serotonin and other neurotransmitters have been studied in intrahippocampal infusion of pilocarpine, a muscarinic receptor agonist; by picrotoxin, a $\mathrm{GABA}_{\mathrm{A}}$ receptor antagonist, and by (R,S)- 3,5-dihydroxyphenylglycine (DHPG), a group I metabotropic glutamate receptor agonist. Acetylcholine is involved in epileptogenesis (Zimmermann et al. 2008). Its application evokes seconds long seizure-like events, these events being totally blocked by the non-specific muscarinic antagonist atropine, and partially by the $\mathrm{M} 1$ receptor antagonist pirenzepine (Zimmermann et al. 2008). The data indicate that administration of acetylcholine and the activation of $\mathrm{M} 1$ receptors have proconvulsive effects. In seizure, increased hippocampal glutamate, GABA, dopamine and acetylcholine levels was reported (Meurs et al. 2008), which is also in tandem with this present study

The activities of the enzymes, COX and G6PDH were assessed. Results showed that COX activity was significantly elevated in the $\mathrm{LiCl}+\mathrm{PC}+\mathrm{AS} 100 \mathrm{mg} / \mathrm{kg}$, $\mathrm{LiCl}+\mathrm{PC}+\mathrm{AS} 300 \mathrm{mg} / \mathrm{kg}$ and $\mathrm{LiCl}+\mathrm{PC}+\mathrm{SV}$ groups when compared to the AS only and $\mathrm{LiCl}+\mathrm{PC}$ groups. $\mathrm{LiCl}+\mathrm{PC}+\mathrm{AS} 300 \mathrm{mg} / \mathrm{kg}$ and $\mathrm{LiCl}+\mathrm{PC}+\mathrm{SV}$ groups also showed increased COX activity when compared to $\mathrm{LiCl}+\mathrm{PC}+\mathrm{AS} 100 \mathrm{mg} / \mathrm{kg}$ group, while $\mathrm{LiCl}+\mathrm{PC}+\mathrm{SV}$ group showed significant increased COX activity when compared to $\mathrm{LiCl}+\mathrm{PC}+\mathrm{AS} 300 \mathrm{mg} / \mathrm{kg}$ group. The brain being one of the tissues having high energy demand requires tightly regulated cellular processes. COX is the last enzyme in the electron transport chain located in the mitochondria and its function in cellular homeostasis is paramount for cell survival and efficient functioning. The extract administered at both low and high doses and the standard drug (sodium valproate) was not able to attenuate $\mathrm{LiCl}+\mathrm{PC}$ induced COX activity.

The importance of G6PDH in the maintenance of cellular homeostasis cannot be underestimated. The cellular antioxidant system plays an important role in the regulation of metabolic stress and inflammation. Oxidative molecules are directly controlled by the reducing ability of nicotinamide adenine dinucleotide phosphate (NAPDH) (Kum-Tatt et al. 1975). NADPH is essential in the cellular antioxidant system as a reducing agent of oxidized glutathione to its reduced frm (Kum-Tatt et al. 1975; Halliwell 1986). G-6-PD is a major enzyme necessary for NADPH production, playing major roles in many essential metabolic pathways and also involved in controlling the generation of ROS and inflammation (Stanton 2012). Results obtained from the present study showed increased G6PDH activity across all experimental groups relative to the control. There was also a significant increase in $\mathrm{LiCl}+\mathrm{PC}+\mathrm{AS} 100 \mathrm{mg} / \mathrm{kg}$, $\mathrm{LiCl}+\mathrm{PC}+\mathrm{AS} 300 \mathrm{mg} / \mathrm{kg}$ and $\mathrm{LiCl}+\mathrm{PC}+\mathrm{SV}$ groups when compared to the AS only and $\mathrm{LiCl}+\mathrm{PC}$ groups. Only the $\mathrm{LiCl}+\mathrm{PC}+\mathrm{SV}$ group showed significant increase when compared to the $\mathrm{LiCl}+\mathrm{PC}+\mathrm{AS} 100$ $\mathrm{mg} / \mathrm{kg}$ and $\mathrm{LiCl}+\mathrm{PC}+\mathrm{AS} 300 \mathrm{mg} / \mathrm{kg}$ groups. AS and SV treatment was not able to attenuate increased G6PDH activity in $\mathrm{LiCl}+\mathrm{PC}$ induced seizures of the present study. Also, dysregulated activity of this enzyme causes severe metabolic stress and inflammation and could be the basis for the neurodegenerative changes seen in this study.

Nitric oxide (NO) levels were significantly increased in the $\mathrm{LiCl}+\mathrm{PC}+\mathrm{AS} 300 \mathrm{mg} / \mathrm{kg}$ and $\mathrm{LiCl}+\mathrm{PC}+\mathrm{SV}$ groups. NO, a ubiquitous gaseous cellular messenger plays significant roles in a variety of neurobiological processes. Several functions of this regulatory molecule have been identified in the nervous system, in the process of endotheliumdependent vasodilatation (Michell et al. 2004; Duncan and Heales 2005; Stojanović et al. 2003, 2004), in neurotransmission (Yamamoto et al. 2015), and in host-defence mechanisms (Boje 2004). Regulation of NO levels is a function of two constitutive isoforms of the enzyme NO synthase (NOS); neuronal NOS (nNOS) and endothelial NOS (eNOS). In several degenerative processes affecting the central nervous system, as well as in brain ischaemia/reperfusion injury triggered and modulated by glutamate, there is a rapid rise in the levels of NO due to hyperactivity of nNOS (Tieu et al. 2003; Hsu et al. 2005). Cytotoxicity in experimental models of seizure seems to be due to the release of glutamate, resulting in the overstimulation of NMDA receptors, 
and leading to prolonged release of $\mathrm{NO}$. There is possibility that excessive NMDA receptor activation, with the consequent increase in intraneuronal $\mathrm{Ca}^{2+}$ through $\mathrm{Ca}^{2+} /$ calmodulin-regulated NOS, enhances the neurotoxicity of glutamate through further release of NO (Hofmann et al. 2006).

Neurobehavioural assessment conducted with the open field test showed significant decrease in walling in the $\mathrm{LiCl}+\mathrm{PC}$ in comparison to control and also in the frequency of rearing in $\mathrm{LiCl}+\mathrm{PC}+\mathrm{AS} 100 \mathrm{mg} / \mathrm{kg}$, $\mathrm{LiCl}+\mathrm{PC}+\mathrm{AS} 300 \mathrm{mg} / \mathrm{kg}$ and $\mathrm{LiCl}+\mathrm{PC}+\mathrm{SV}$ groups when compared with Allium sativum only. However, there was no significant difference in other parameters tested. The radial arm-maze apparatus was used to assess working memory in the study. There was no significant difference in working memory assessed across groups.

\section{Conclusion}

By putting together, the data from this study, AS demonstrated anti-seizure potentials through its improvement of neuronal structures and mitigating reactive astrogliosis. However, the mechanism by which AS improved neuronal structure and function is not neurotransmitter dependent as glutamate levels and activities of enzymes assayed were not lowered following AS treatment.

\section{Conflict of Interest}

None declared.

\section{Author Contributions}

SYO and ASA conducted the experiments, performed biochemical investigations, and assisted in the writing of the manuscript. POO designed the study. He had a lead role in drafting the article and reviewed the final manuscript. JOO played an active role in the arrangement of resources and served as the project's supervisor. JAO and ASA performed statistical analysis and contributed to the interpretation of the results. STA performed the immunohistochemical and histological studies, interpreted the immunohistochemical results with the scale bar, and wrote the comments. AZA prepared figures and helped in the writing of the manuscript.

\section{REFERENCES}

Agarwal, K.C. (1996) Therapeutic actions of garlic constituents. Med Res Rev.16(1):111-124.

Amini, E., Rezaei, M., Mohamed, I.N., Golpich M., Ghasemi R. and Mohamed Z. (2015) A molecular approach to epilepsy management: from current therapeutic methods to preconditioning efforts. Mol Neurobiol. 52(1):492-513.

Ashrafi, M.R., Shams, S., Nouri, M., Mohseni, M., Shabanian, R., Yekaninejad, M.S., et al. (2007) A probable causative factor for an old problem: selenium and glutathione peroxidase appear to play important roles in epilepsy pathogenesis. Epilepsia. 48(9):1750-1755.

Belgin, I., Seref, G. and Radojko, J. (2005) Determination of selenium in garlic (Allium sativum) and onion (Allium cepa) by electrothermal atomic absorption spectrometry. Food Chem. 99:630-637.

Boje, K.M. (2004) Nitric oxide neurotoxicity in neurodegenerative diseases. Front Biosci. 9:763-776. Brigo, F., Storti, M., Del Felice, A., Fiaschi, A. and Bongiovanni, L.G. (2012) IV Valproate in generalized convulsive status epilepticus: a systematic review. Eur J Neurol 19(9):1180-1191.

Caravati, E.M. (2004) Medical Toxicology (3rd edn.). Philadelphia: Lippincott Williams \& Wilkins.

Carmia, B. (2006) Garlic reduces dementia and heart disease risk. J Nutr. 136:810S-812S.

Choudhary, N., Bijjem, K.R.V. and Kalia, A.N. (2011) Antiepileptic potentials of flavonoids fraction from the leaves of Anisomeles malabarica. J Ethnopharmacol. 135(2):238-242.

Clasadonte, J. and Haydon, PG. (2012) Astrocytes and epilepsy. In Jasper's Basic Mechanisms of the Epilepsies. Noebles, J.L., Avoli, M., Rogawski, M.A., Olsen, R.W. and Delgado-Escueta, A.V. (eds.). Bethesda: National Center for Biotechnology Information: 19

Diniz, T.C., Silva, J.C., Lima, S.S.R.G., Ribeiro, F.P.R.A., Pacheco, A.G.M., Freitas, R.M., et al. (2015) The role of flavonoids on oxidative stress in epilepsy. Oxidative Med Cellular Longevity. Pp 1-9.

Divya, B., Bukke, S. and Venkataswamy, M. (2017) A study on phytochemicals, functional groups and mineral composition of Allium sativum (garlic) cloves. Int J Curr Pharm Res. 9:1-3

Duncan, A.J. and Heales, S.J. (2005) Nitric oxide and neurological disorders. Mol Aspects Med. 26:67-96.

Fisher, R.S., van Emde Boas, W., Blume, W., Elger, C., Genton, P., Lee, P., et al. (2005) Epileptic seizures and epilepsy: definitions proposed by the International League against Epilepsy (ILAE) and the International Bureau for Epilepsy (IBE). Epilepsia. 46(4):470-472.

Goldberg, E.M. and Coulter, D.A. (2013) Mechanisms of epileptogenesis: a convergence on neural circuit dysfunction. Nat Rev Neurosci. 14(5):337-349.

Halliwell, B. (1986) Effect of oxidized glutathione on the inhibition of glucose-6-phosphate dehydrogenase by NADPH. Biochem J. 234(3):741.

Hernan, A., Alexander, A. and Jenks, K.R. (2014) Focal epileptiform activity in the prefrontal cortex is associated with long-term attention and sociability deficit. Neurobiol Dis. 63:25-34.

Hitiris, N., Mohanraj, R. and Norrie, J. (2007) Mortality in epilepsy. Epilepsy Behav. 10(3):363-376. Hofmann, F., Feil, R. and Kleppisch, T. (2006) Function of cGMP-dependent protein kinases as revealed by gene deletion. Physiol Rev. 86:1-23.

Hsu, M., Srinivas, B. and Kumar, J. (2005) Glutathione depletion resulting in selective 
mitochondrial complex I inhibition in dopaminergic cells is via an NO-mediated pathway not involving peroxynitrite: implications for Parkinson's disease. J Neurochem. 92:1091-1103.

Jacob, T.C., Moss, S.J. and Jurd, R. (2008) GABAA receptor trafficking in the dynamic modulation of neuronal inhibition. Nat. Rev. Neurosci. 9:331-343.

Kalozoumi, G., Kel-Margoulis, O., Vafiadaki, E., Greenberg, D., Bernard, H. and Soreq, H. (2018) Glial responses during epileptogenesis in Mus musculus point to potential therapeutic targets. PLoS ONE. 13(8):e0201742.

Khan, O.I., Zhao, Q., Miller, F. and Holmes, G.L. (2010) Interictal spikes in developing rats cause longstanding cognitive deficits. Neurobiol Dis. 39(3):362371.

Kum-Tatt, L., Tan, I.K. and Seet, A.M. (1975) A new colorimetric method for the determination of NADH/NADPHM-dependent glutathione reductase in erythrocytes and in plasma. Clin Chim Acta. 58(2):101-108.

Lin, T.Y., Lu, C.W., Wang, C.C., Lu, J.F. and Wang, S.J. (2012) Hispidulin inhibits the release of glutamate in rat cerebrocortical nerve terminals. Toxicol Applied Pharmacol. 263(2):233-243

Magiorkinis, E., Sidiropoulou, K. and Diamantis, A. (2010) Hallmarks in the history of epilepsy: epilepsy in antiquity. Epilepsy Behav. 17(1):103-108 doi: 10.1016/j.yebeh.2009.10.023.

Meurs, A., Clinckers, R., Ebinger, G., Michotte, Y. and Smolders, I. (2008) Seizure activity and changes in hippocampal extracellular glutamate, GABA, dopamine and serotonin. Epilepsy Res. 78:50-59.

Michell, A.W., Lewis, S.J. and Foltynie, T. (2004) Biomarkers and Parkinson's disease. Brain.127:1693-1705.

Olatunji, S.Y, Ogunnaike. O.P., Owolabi, J.O., Adelodun, S.T., Ogunnaike, A.E., Adegbola, G.M. (2020) Parkia clappertoniana mitigated neuronal damage in the hippocampus in lithium chloridepilocarpine-induced epilepsy in wistar rat model. J Anat Sci. 11.171-179.

Perucca, P. and Gilliam F.G. (2012) Adverse effects of antiepileptic drugs. Lancet Neurol. 11(9):792-802.

Ray, B., Chauhan, N.B. and Lahiri, D.K. (2011) Oxidative insults to neurons and synapse are prevented by aged garlic extract and S-allyl-Lcysteine treatment in the neuronal culture and APPTg mouse model. J Neurochem. 117(3):388-402.

Rivlin, R.S. (2001) Historical perspective on the use of garlic. J Nutr. 131(3):9515-9545.

Sharma, S., Carlson, S., Puttachary, S., Sarkar, S., Showman, L. and Putra, M. (2018) Role of the Fyn-
PKCס signaling in SE-induced neuroinflammation and epileptogenesis in experimental models of temporal lobe epilepsy. Neurobiol Dis. 110:102-121.

Stanton, R.C. (2012) Glucose-6-phosphate dehydrogenase, NADPH, and cell survival. IUBMB Life. 64(5):362-369.

Stojanović, R., Todorović, Z. and Nešić, Z. (2003) NG-nitro-L-arginine methyl ester potentiates the effect of aminophylline on the isolated rat hemidiaphragm. J Pharmacol Sci. 92:157-162.

Stojanović, R., Todorović, Z. and Nešić, Z. (2004) NG-nitro-L-arginine methyl ester-induced potentiation of the effect of aminophylline on rat diaphragm: the role of extracellular calcium. J Pharmacol Sci. 96:493-498.

Tascos, N.A., Parr, J. and Gonatas, N.K. (1982) Immunocytochemical study of the glial fibrillary acidic protein in human neoplasms of the central nervous system. Hum Pathol. 13(5):454-458.

Thurman, D.J., Beghi, E., Begley, C.E., Berg, A.T., Buchhalter, J.R., Ding, D., et al. (2011) Standards for epidemiologic studies and surveillance of epilepsy. Epilepsia. 52(S7):2-26.

Tieu, K., Ischiropoulos, H. and Przedborski, S. (2003). Nitric oxide and reactive oxygen species in parkinson's disease. IUBMB Life. 55(6):329-335. doi:10.1080/1521654032000114320

Waldbaum, S. and Patel, M. (2010) Mitochondrial dysfunction and oxidative stress: a contributing link to acquired epilepsy? J Bioenerg Biomembr. 42(6):449455.

Werner, F.M. and Coveñas, R. (2011) Classical neurotransmitters and neuropeptides involved in generalized epilepsy: a focus on antiepileptic drugs. Current Med Chem. 18(32):4933-4948.

WHO (2015) Epilepsy. Fact Sheet No. 999. Geneva: World Health Organization, 2015. Available at: http:// www.who.int/mediacentre/factsheets/fs999/en/index. $\underline{\text { html }}$

Wichai T., Pannangrong W., Welbat J., Chaichun A., Sripanidkulchai K. and Sripanidkulchai B. (2019) Effects of aged garlic extract on spatial memory and oxidative damage in the brain of amyloid- $\beta$ induced rats. Songklanakarin J Sci Technol. 41:311-318.

Yamamoto, K., Takei, H. and Koyanagi, Y. (2015) Presynaptic cell type-dependent regulation of GABAergic synaptic transmission by nitric oxide in rat insular cortex. Neurosci. 284:65-77.

Zimmermann, G., Njunting, M., Ivens, S., Tolner, E., Behrens, C.J., Gross, M., et al. (2008) Acetlycholineinduced seizure-like activity and modified cholinergic gene expression in chronically epileptic rats. Eur $\mathrm{J}$ Neurosci. 27:965-975.

Cite as Olatunji S.Y. Ogunnaike, P.O., Owolabi, J.O., Abijo, A.Z., Alabi, A.S., Adelodun, S.T., Olanrewaju, J.A. and Adelabi. A.S. (2021) Investigating the effects of allium sativum on the prefrontal cortex in lithium chloride pilocarpine-induced epilepsy in Wistar rat. Nig. J. Neurosci. 12(2):56-66. http://doi.org/10.47081/njn2021. 12.2/003 